\title{
Belantara Foundation sebagai Media Komunikasi Lingkungan
}

\author{
Muhammad Jamiluddin Nur ${ }^{1}$, Junaidi ${ }^{2}$ \\ ${ }^{1}$ Program Studi Ilmu Komunikasi Universitas Mataram, ${ }^{2}$ Program Studi Sosiologi, Universitas Lampung \\ jamilnur@unram.ic.id

\section{Belantara Foundation as the Media of Environmental Communication}

\begin{abstract}
Information and news in the mainstream media about the environment often do not get the same intensity or duration when compared with political and economic news. It causes the community to not get the maximum information about damage, anticipation, and environmental preservation. This study purposes of describing the role of Belantara Foundation both as a social organization and a media in providing information about the environment. The method used in this research is descriptive qualitative. Researchers collect data by observing on social media. Through these observations, researchers looked at information distributed by the Belantara Foundation social media and used as data. This research explains that the Belantara Foundation, as one of the organizations with social media account can raise public awareness regarding environmental damage and preservation, has enormous potential to safeguard common interests related to environmental issues. Belantara Foundation's social media has carried out informative and environmental tasks. What should be done in the future by Belantara Foundation is consistency in providing information about the environment. Also, collaboration with environmental scientists to provide information to the public must continue to be carried out in order to maintain the validity of information regarding damage, anticipation and preservation of the environment.
\end{abstract}

Keywords: Belantara Foundation; Media; Environmental communication

\begin{abstract}
ABSTRAK
Informasi dan berita di media mainstream mengenai lingkungan sering kali tidak mendapatkan intensitas maupun durasi yang sama jika dibandingkan dengan berita politik dan ekonomi. Hal ini menyebabkan masyarakat tidak maksimal dalam mendapatkan informasi mengenai kerusakan, antisipasi, dan pelestarian lingkungan. Tujuan penelitian ini adalah untuk mendeskripsikan peran Belantara Foundation baik sebagai Lembaga kemasyarakatan maupun sebagai media dalam memberikan informasi mengenai lingkungan. Metode yang digunakan adalah deskriptif kualitatif. Peneliti mengumpulkan data dengan melakukan observasi di media sosial. Melalui observasi tersebut, peneliti mencermati informasi yang disebarkan media sosial Belantara Foundation dan digunakan sebagai data. Penelitian ini menjelaskan bahwa Belantara Foundation sebagai salah satu organisasi yang memiliki media sosial untuk menyadarkan masyarakat terkait kerusakan dan pelestarain lingkungan memiliki potensi yang sangat besar untuk mengawal kepentingan bersama terkait isu lingkungan. Pada dasarnya, media sosial yang dimiliki Belantara Foundation telah melakukan tugas-tugas informatif dan mengenai lingkungan. Hal yang patut dilakukan ke depan oleh Belantara Foundation adalah konsistensi dalam memberikan informasi mengenai lingkungan. Selain itu, kerjasama dengan ilmuwan lingkungan untuk memberikan informasi kepada masyarakat harus terus dilakukan guna menjaga validitas informasi mengenai kerusakan, antisipasi dan pelestarian lingkungan.
\end{abstract}

Kata kunci: Belantara Foundation; Media; Komunikasi Lingkungan 


\section{PENDAHULUAN}

Sejak tahun 2014 silam, Belantara Foundation telah menjadi salah satu media yang digunakan oleh para aktivis lingkungan di wilayah Kalimantan dan Sumatera untuk mengkomunikasikan dan mengampanyekan isu lingkungan. Pada dasarnya, Belantara Foundation merupakan Lembaga Swadaya Masyarakat (LSM) yang bergerak aktif dalam bidang lingkungan dan berpusat di Jalan Timor no 6 Menteng DKI Jakarta. Lembaga ini sebagai salah satu modal sosial untuk membangun kesadaran di tengah masyarakat akan lingkungan di Indonesia pada umumnya dan daerah Kalimantan, Sumatera pada khususnya.

Sebagai lembaga masyarakat, organisasi ini kerap kali melakukan kegiatan-kegiatan pelatihan kepada masyarakat untuk aktif dalam gerakan peduli lingkungan. Selain itu, kampanye-kanpenye tentang kepedulian terhadap lingkungan selalu dilakukan oleh lembaga ini salah satunya melalui media sosial Belantara Foundation. Pada dasarnya, media massa mainstream memiliki tanggung jawab sosial untuk memberikan kesadaran kepada masyarakat akan pentingnya kepedulian terhadap lingkungan.

Media massa merupakan kekuatan dalam menyebarkan informasi. Daya jangkau media massa juga mampu hadir di berbagai lapisan sosial, ekonomi dan politik. Dengan perannya sebagai salah satu sumber informasi untuk memperoleh pengetahuan dan wawasan, media massa harus digunakan untuk mengelola lingkungan. Hal ini tentu dapat dilakukan melalui konten dan pemberitaan yang menarik. Senada dengan itu, Lippman (dalam Schramm, 1970) menegaskan media berperan dalam penyebaran informasi, sekaligus dapat membentuk persepsi khalayak sehingga melalui media massa seperti surat kabar, radio dan tv masyarakat dapat mengetahui apa yang terjadi di sekitar mereka dan di tempat lain.

Persoalan datang ketika informasi mengenai lingkungan tidak dipandang penting oleh media mainstream, penerapan media massa sebagai sumber informasi untuk mengelola lingkungan kemudian sulit dilakukan. Pasalnya, media massa kemudian lebih mementingkan nilai kalkulasi ekonomi dalam memberikan informasi kepada masyarakat. Keadaan ini berpotensi menyampingkan kepentingan bersama demi nilai ekonomi untuk pemilik media atau golongan tertentu. Memberikan kesadaran kepada masyarakat akan lingkungan kemudian menjadi semakin sulit. Gerakan masyarakat secara mandiri dalam tahap ini sangat dibutuhkan. Belantara Foundation hadir di tengah masyarakat untuk memberikan kesadaran untuk mengelola lingkungan salah satunya adalah dengan menggunakan media sosial sebagai wahana komunikasi terkait isu lingkungan.

Sementara itu, perkembangan teknologi komunikasi kini telah memberikan ruang yang lebih bagi masyarakat untuk mengkampanyekan kesadaran akan lingkungan, terutama melalu media sosial. Hadirnya media sosial memberikan kebebasan bagi masyarakat untuk mengelola medianya sendiri. Dengan demikian, tendensi mengutamakan nilai ekonomi dalam menyebar informasi bisa diminimalisir. Dinamika hadirnya teknologi komunikasi ini kemudian dimanfaatkan oleh Belantara Foundation sebagai gerakan masyarakat untuk melakukan 
kampanye tentang lingkungan. Selain kampanye, penyebaran kegiatan pelatihan dan sosialisasi di berbagai daerah juga ditampilkan melalui media sosial Belantara Foundation ini. Hal inilah yang menarik perhatian penulis untuk membahas mengenai Belantara Foundation.

Sementara itu, tujuan dari artikel ini adalah untuk membahas mengenai media sosial Belantara Foundation sebagai media komunikasi lingkungan. Selain itu, tujuan penulis melakukan penelitian ini adalah untuk menambah khazanah penelitian mengenai media dan komunikasi lingkungan.

\section{METODE}

Metode yang penulis gunakan dalam tulisan ini adalah metode penelitian deskriptif kualitatif. Mulyana (2013), mengartikan penelitian kualitatif sebagai penelitian yang bersifat interpretatif yang bisa melibatkan banyak metode dalam menelaah masalah penelitian. Secara teknik pengumpulan data, penulis menggunakan teknik observasi di media sosial. Informasiinformasi yang dibagikan oleh media sosial Belantara Fondation peneliti cermati kemudian dijadikan data. Selain itu, penulis juga melakukan studi literatur untuk memperkuat argumentasi dalam menginterpretasikan dan mendeskripsikan mengenai data yang penulis temukan setelah melakukan observasi.

\section{HASIL DAN PEMBAHASAN}

Menurut undang-undang no 32 tahun 2009 tentang perlindungan dan pengelolaan lingkungan (PPLH), lingkungan hidup adalah kesatuan ruang dengan semua benda, daya, keadaan dan makhluk hidup, termasuk manusia dan perilakunya, yang mempengaruhi alam itu sendiri, kelangsungan perikehidupan dan kesejahteraan manusia serta makhluk hidup lain. Jadi pada dasarnya, sudah seharusnya semua kalangan masyarakat termasuk melalui media untuk menjaga lingkungan dan segala eksistensinya.

Nilai kepedulian terhadap lingkungan hidup baik dalam pembangunan maupun pelestarian tidak harus selalu mengenai penyelamatan, pelestarian, dan pengelolaan lingkungan hidup. Akan tetapi kepedulian terhadap lingkungan hidup dapat pula dilakukan melalui penyebaran informasi maupun pemberitaan melalui media. Hal inilah yang dilakukan Belantara Foundation. Selain aktif dalam menyelamatkan dan melestarikan lingkungan, LSM ini juga melakukan penyebaran berita dan informasi melalui media sosial facebook dan twitter. Tindakan ini tentu patut untuk diapresiasi ditengah miskinya pemberitaan media massa konvensional dalam memberitakan isu yang berkaitan dengan lingkungan. Seringnya, isu terkait lingkungan kalah seksi dengan isu politik, ekonomi bahkan agama.

Jika media mainstream dan media sosial rajin menampilkan dan menyebarkan informasi yang mampu membangun kepedulian terhadap lingkungan, maka diharapkan masyarakat akan memiliki wawasan dan kesadaran untuk menjaga dan melestarikan lingkungan. Tidak dipungkiri bahwa media massa memiliki kemampuan untuk mempengaruhi individu maupun kelompok 
sosial masyarakat. Mcquail (2010), mengatakan media paling baik digunakan secara terencana untuk menimbulkan perubahan dengan menerapkannya dalam program pembangunan skala besar.

Dengan keadaan media massa konvensional yag jarang memberitakan lingkungan saat ini, maka dibutuhkan media sosial untuk melakukan apa yang dikatakan oleh Mcquail tersebut. Sejatinya media massa konvensional harus berperan dalam mengelola lingkungan. Sneider (dalam Priest, 2010), bahkan mengatakan wartawan media harus bekerjasama dengan ilmuan untuk memberikan kepastian informasi mengenai lingkungan.

Dalam pandangan Craft, Light dan Godfrey (2001), komunikasi adalah proses penting yang mengikat masyarakat untuk bersama-sama terlibat dalam komunikasi interpersonal antar individu dan kelompok. Dalam konteks ini, media sosial yang dimiliki Belantara Foundation dapat dilihat sebagai proses penting yang mengikat masyarakat untuk bersama-sama terlibat dalam menjaga dan melestarikan lingkungan. Informasi tentang kegiatan dan kampanye kepedulian terhadap lingkungan yang dilakukan media ini berpotensi digunakan secara terencana untuk menimbulkan perubahan. Selain itu, media ini juga bekerjasama dengan para ilmuan untuk memberikan informasi tentang lingkungan seperti yang terlihat dalam pelatihanpelatihan yang dilakukannya.

Pada konteks ini, Belantara Foundation merupakan salah satu unsur dalam masyarakat yang dapat dijadikan kekuatan dalam melestarikan lingkungan. Kelestarian lingkungan dapat dibangun jika dilakukan secara integratif antara LSM, pemerintah, perusahaan swasta dan masyarakat umumnya termasuk media massa. Menurut Clella (2010), terjadi komunikasi transaksional yang menciptakan makna bersama. Dengan kesamaan pandangan antar entitas dalam pemeliharaan lingkungan dapat berjalan dengan baik dan mampu menumbuhkan partisipasi masyarakat dalam menjaga lingkungan.

Seperti yang telah penulis paparkan bahwa pemeliharaan terhadap lingkungan bukan hanya tanggung jawab pemerintah saja akan tetapi tangung jawab segenap masyarakat yang ada di negara Indonesia. Hal ini tertuang dalam UU no 32 tahun 2009 yang mengatakan bahwa perlindungan dan pengelolaan lingkungan hidup dilaksanakan berdasarkan asas : (a) tanggung jawab negara, (b) kelestarian dan keberlanjutan, (c) keserasian dan keseimbangan, (d) keterpaduan, (e) manfaat, (f) kehati-hatian, (g) keadilan, (h) ekoregion, (i) keanekaragaman hayati, (j) pencemar membayar, (k) partisipatif, (I) kearifan lokal, $(\mathrm{m})$ tata kelola pemerintahan yang baik, $(n)$ otonomi daerah. Dengan demikian, dapat kita pahami bahwa semua masyarakat berperan aktif dalam menjaga kelestarian lingkungan dengan asas kearifan lokal dan partisipatif.

Peran aktif masyarakat tentu dapat beragam dalam berbagai bidang dan keahlian. Jika akademisi bekerjasama dengan media untuk memberikan informasi yang pasti terkait dengan lingkungan, maka masyarakat umum juga dapat bergerak melalui berbagai bidang karena hal tersebut telah dijamin sebagai hak konstitusi masyarakat dan tertuang dalam UU tersebut. 
Dengan peran aktif masyarakat tersebut, diharapkan keterbukaan publik semakin terbangun tidak terkecuali dalam hal lingkungan. Masyarakat harus mendapat wawasan dan pengetahuan tentang lingkungan karena hal ini menyangkut ruang hidup bersama. Selain itu, baik media massa konvensional maupun Belantara Foundation sebagai media sosial untuk menyalurkan informasi, harus berpegang teguh pada jaminan bagi masyarakat untuk mendapatkan informasi mengenai lingkungan. Senada dengan yang tercantum dalam UU no 14 tahun 2008 tentang keterbukaan informasi publik.

Dengan dasar UU tersebut, maka masyarakat memiliki hak untuk direspon oleh media masa dalam memberikan keterbukaan informasi mengenai lingkungan. Belantara Foundation sendiri sebagai media komunikasi, juga harus memberikan informasi-informasi yang berasaskan keterbukaan. Dengan demikian, masyarakat memiliki kesempatan mendapatkan wawasan dan pengetahuan yang lebih luas tentang lingkungan. Melalui wawasan dan pengetahuan tersebut kita harapkan kesadaran untuk menjaga dan melestarikan lingkungan dapat terbangun.

Belantara Foundation sebagai salah satu media sosial yang hadir di tengah masyarakat memiliki kekuatan dalam menggerakkan dan memberikan kesadaran pada masyarakat. Hal ini harus disadari oleh Belantara Foundation sendiri. Media sosial cukup potensial dalam memberikan informasi menuju gerakan perubahan. Besarnya pengguna internet dan media sosial di Indonesia cukup menjadi gambaran betapa potensialnya media sosial. Berdasarkan data lembaga We Are Social pada bulan Januari 2014, dari total 251.160.124 jumlah populasi masyarakat Indonesia, 38.191.873 pengguna internet. Sementara itu, jumlah pengguna aktif Facebook adalah 62.000.000 (Nasrullah, 2015).

Dengan melihat data pengguna internet dan media sosial di atas, kita bisa melihat bahwa media sosial Belantara Foundation harus hadir sebagai partner pemerintah dalam mengampanyekan urgensi akan kepedulian masyarakat terhadap lingkungan. Permasalahan lingkungan di Indonesia saat ini bukan hanya mengenai rusaknya alam dan terjadinya berbagai bencana seperti banjir, longsor, kebakaran hutan, hingga kekayaan flora dan fauna yang rawan diperjualbelikan. Akan tetapi, masalah komunikasi dan kampanye mengenai kerusakan lingkungan hidup, kepastian informasi dalam merespon dan mengantisipasi perkembangan rusaknya lingkungan hidup yang masih sangat minim. Melalui media sosial dan gerakan nyata, Belantara Foundation dapat menjadi salah satu elemen penting baik di wilayah Kalimantan dan Sumatera pada khususnya dan Indonesia pada umumnya.

Media sosial yang dimiliki Belantara Foundation saat ini memang belum ditanggapi secara serius. Akan tetapi, jika dilakukan dengan konsisten postingan konten dan penyebaran informasi mengenai lingkungan, masyarakat dapat menjadikannya sebagai referensi dalam hal memahami, merespon hingga mengantisipasi dampak kerusakan lingkungan. Hal ini harus dirancang para pegiat media sosial Belantara Foundation sebagai agenda utama. Perhatian terhadap isu lingkungan harus konsisten dilakukan guna mempengaruhi masyarakat untuk memiliki kesadaran lingkungan. Mc. Combs (dalam Littlejohn, 2014) mengatakan bahwa 
perhatian media terhadap isu-isu tertentu, dapat mempengaruhi perhatian masyarakat atas isu tersebut.

\section{Media Sosial Belantara Fondation dan Gerakan Masyarakat}

Seperti data yang telah dijabarkan sebelumnya, bahwa pengguna internet dan media sosial di Indonesia sangat banyak. Data tersebut dapat menjadi acuan pegiat media sosial Belantara Foundation untuk menyadari pentingnya melakukan kampanye mengenai lingkungan melalui media sosial. Target yang dapat dijangkau dengan demikian bisa lebih luas.

Permasalahan media massa mainstream di Indonesia saat ini belum memberikan ruang yang luas untuk isu lingkungan. Untuk menyiasati hal tersebut, media sosial memiliki potensi yang luar biasa untuk menyebarkan informasi kepada masyarakat. Langkah yang telah diambil oleh Belantara Foundation sejauh ini sudah tepat dengan membuat akun di media sosial Facebook dan Twitter akan tetapi dibutuhkan konsistensi untuk menyebarkan informasi kepada masyarakat.

Kekuatan media sosial dalam mengubah perilaku masyarakat saat ini tidak bisa dipungkiri. Berbagai riset mengenai media sosial dan hubungannya dengan masyarakat telah dilakukan. Penelitian tentang revolusi yang terjadi di Tunisia dan Mesir telah menunjukkan kepada kita dampak yang bisa diakibatkan oleh kecanggihan teknologi komunikasi saat ini. Revolusi tersebut tidak terlepas dari seruan perlawanan yang dilakukan masyarakat melalui berbagai saluran termasuk media sosial twitter (Lotan,dkk, 2011). Selain itu, dalam bidang budaya, penelitian di Afrika mengenai media sosial sebagai wahana untuk belajar tentang adat istiadat yang dinilai penting dalam membangun sosial dan ekonomi yang dilakukan Owiny (2014), telah menunjukkan bahwa teknologi komunikasi membawa perubahan yang dapat dimanfaatkan untuk membangun masyarakat.

Sementara itu, media sosial sebagai salah satu yang mempengaruhi Gerakan masyarakat juga dapat dilhat dari kasus "Gerakan Payung" yang terjadi di Hongkong. Hasil penelitian Lin (2017), menunjukkan bahwa ada kecenderungan kebangkitan teori ekologi media dalam memandang kasus tersebut. Artinya, media sosial dan gerakan payung juga dapat dilihat sebagai bukti kekuatan media menyampaikan pesan protes dan perlawanan yang dilakukan oleh masyarakat Hongkong. Pengaruh sosial media juga terlihat dalam gerakan protes yang terjadi di Brazil 2013 silam. Dari penelitian Cardoso (2016), kita bisa melihat gerakan tersebut tidak terlepas dari banyaknya postingan di media sosial yang ikut mendorong gerakan protes tersebut.

Dari beberapa data hasil penelitian tersebut, maka Belantara Foundation sejatinya memiliki potensi yang luar biasa untuk menjadi media yang fokus untuk mengkomunikasikan dan mengkampanyekan isu lingkungan. Belantara Foundation memiliki kekuatan serta peluang untuk menjadi media yang mampu menggerakkan masyarakat yang mencerminkan perilaku 
yang lebih peduli terhadap kelestarian lingkungan hidup dan bergerak mengantisipasi segala kerusakan yang terjadi pada lingkungan.

Melalui media sosial, Belantara Foundation juga mampu membuat masyarakat terlibat aktif dalam memberikan gagasan dan wawasan mengenai lingkungan. Kemampuan ini dikarenakan karakteristik yang dimiliki media sosial salah satunya adalah membentuk jaringan. Dengan jaringan tersebut, para penggunanaya bisa aktif dalam membagikan hingga menuangkan komentar atau argumentasinya (Lihat Nasrullah, 2015). Pola pemberian ruang diskusi publik melalui media sosial dapat dilakukan secara konsisten sesuai dengan amanah UU tentang pengelolaan dan pelestarian lingkungan yang berasaskan nilai partisipatif seperti yang tertera dalam UU no 32 tahun 2009.

\section{SIMPULAN}

Gerakan masyarakat untuk melakukan perubahan dapat terjadi karena berbagai faktor, salah satunya adalah konsistensi media dalam memperhatikan sebuah isu. Berbagai penelitian membuktikan bahwa media sosial dan internet telah membawa perubahan di berbagai belahan dunia. Belantara Fondation sebagai salah satu organisasi yang memiliki media sosial untuk menyadarkan masyarakat terkait kerusakan dan pelestarain lingkungan memiliki potensi yang sangat besar untuk mengawal kepentingan bersama terkait isu lingkungan. Pada dasarnya, media sosial yang dimiliki Belantara Fondation telah melakukan tugas-tugas informatif dan mengenai lingkungan. Hal yang patut dilakukan ke depan oleh Belantara Fondation adalah konsistensi dalam memberikan informasi mengenai lingkungan. Selain itu, kerjasama dengan ilmuan untuk memberikan informasi kepada masyarakat harus terus dilakukan guna menjaga validitas informasi mengenai kerusakan, antisipasi dan pelestarian lingkungan.

\section{DAFTAR PUSTAKA}

Cardoso, L, \& F. (2016). People Are the Message? Social Mobilization and Social Media in Brazil, International Journal of Communication, 10, 3909-3930

Craft, J.E, Frederich A. Light \& Donald G. Godfrey. (2001). Electroinic Media. Australia: Wadsworth Thompson Learning

Jafee. C. (2010). Public Speaking : Concepst and Skill for a Diverse Soceity. Sixth Edition. China: Wadshword Cengege Learning.

Lin, Z. (2017). Contexstualized Transmedia Mobilization: Media Practices and Mobilizing Structures in the Umberlla Movement, International Journal of Communication, 11, 48-71.

Littlejohn \& Foss. (2014). Teori Komunikasi (edisi 9). Jakarta: Salemba Humanika

Lippman, W. 1970. "The World Outside and The Pictures".dalam Mass Communication, Wilbur Schramm (ed). Urbana: University of Illinois Press. 
Lotan, G, A, G, P \& Boyd. (2011). The Revolution Were Tweeted: Information Flows During The 2011 Tunisian and Egyptian Revolutions, International Journal of Communication, 5, 1375-1405.

Mcquail, D. 2010. Mass Communication Theory: An Intoduction Sixth Edition. London: Sage Publication Mulyana, D. (2013). Metode Penelitian Komunikasi: Contoh-Contoh Penelitian Kualitatif Dengan Pendekatan Praktis. Bandung: PT Remaja Rosdakarya.

Nasrullah. (2015). Media Sosial Perspektif Komunikasi, Budaya, dan Sosioteknologi. Bandung: Simbiosa Rekatama Media

Owiny, M, \& Maretzki. (2014). The Use of Social Media Technologies to Create, Preserve, and Disseminate Indigenous Knowledge, and Skills to Communities in East Africa. International Journal of Communication, 8, 234-247

Sneider, J. (2010). Making Space for The Nuance of Truth : Communication and Uncertainty at an Environmental Journalist Workshop dalam Susanna Hornig Priest (ed). Science Communication, Volume 32 number 2 June. 2010, Las Vegas: Sage Publication. 